\title{
A laminin-rich basement membrane matrix influences estrogen receptor $B$ expression and morphology of MDA-MB-231 breast cancer cells
}

\author{
HANS NEUBAUER* ${ }^{*}$, ALEXANDRA RUOFF* , NICOLE PAESSLER, ERICH SOLOMAYER, \\ DIETHELM WALLWIENER and TANJA FEHM
}

Department of Obstetrics and Gynaecology, University of Tuebingen, 72076 Tuebingen, Germany

Received July 23, 2008; Accepted September 30, 2008

DOI: $10.3892 /$ or_00000247

\begin{abstract}
The expression of the estrogen receptor $\beta$ (ERß) has been shown to play an important role in breast cancer. There is emerging hope that ERß and its isoforms will be used as prognostic markers or as therapeutic targets in the clinical management of breast cancer. Many studies indicate that ERß is down regulated during carcinogenesis. However, it is still unknown which signals can regulate ERß expression. Basement membrane (BM) components have been shown to influence the expression levels of $\mathrm{ER} \alpha$ and progesterone receptor. Therefore, we hypothesized that cell-matrix interactions can also affect the expression of ERß and its isoforms. To test this we performed Matrigel assays using an $\mathrm{ER} \alpha$ negative breast cancer cell line. MDA-MB-231 cells were plated on Matrigel, a reconstituted laminin-rich BM matrix, or on uncoated plastic culture plates. To investigate the effects of specific BM components we also cultured the cells on gels of purified collagen type IV and laminin-111. ERß expression levels were investigated after 24, 48 and $72 \mathrm{~h}$ by RT-PCRs which allow to distinguish between different ERß isoforms. MDA-MB-231 cells cultured on tissue culture plastic showed increased levels of ERß1 mRNA after $48 \mathrm{~h}$. However, in cells cultured on Matrigel signals for ERß1 expression stayed at very low, nearly undetectable levels. Laminin-111 was identified to be the protein that represses ERß1 expression at the mRNA stage. Collagen type IV showed no effect on ERß expression. We further observed that MDA-MB-231 cells on Matrigel organize into cell aggregates which are connected in web-like structures that appear similar to lactiferous ducts. These data suggest that interactions of breast cancer cells with the BM protein
\end{abstract}

Correspondence to: Dr Hans Neubauer, Calwerstr. 7/6, BadenWuerttemberg, 72076 Tuebingen, Germany

E-mail: hans.neubauer@med.uni-tuebingen.de

${ }^{*}$ Contributed equally

Key words: basement membrane, laminin-111, estrogen receptor $\beta$ laminin-111 suppress the expression of ERß1 at the mRNA level. A laminin-111-rich microenvironment seems to keep ERß1 at very low levels in breast cancer cells.

\section{Introduction}

Estrogen receptor $\beta$ in breast cancer. Decision making in the clinical management of breast cancer is to a great extent guided by estrogen receptor (ER) expression. The definition of ER status still relies only on the expression of ER $\alpha$ (1). But since the discovery of a second ER, ERß (2) and its variant isoforms the definition of ER status and its clinical value has become more complex. Many studies indicate a crucial role of ERß and its isoforms for the prognosis and the therapeutic management of breast cancer (1,3-6). Various ERß isoforms have been identified. Most of them are splice variants or exon deletion isoforms (7). The currently best characterized isoforms are ERß1 (wild type), ERß2 (identical to ERßcx), ERß3, ERß4, ERß5 and ERß 45 (lacking exon 5) (3-5). Several studies confirmed their existence as full length transcripts (1). ERß has been shown to be expressed in normal mammary gland tissue as well as in malignant tumours (1). Many studies have been focused on the role of ERß in breast cancer. However, the results and conclusions are still conflicting. There is emerging evidence that the different ERß isoforms may have different biological functions or clinical values (3-5,8-11). The challenge remains of developing a standardized scoring system for immunohistochemical detection of ERß and its isoforms $(1,12,13)$. A series of studies indicate a role of ERB1 as a tumour suppressor. During carcinogenesis expression of ERß1 is decreased in relation to $\operatorname{ER} \alpha(13-16)$, a fact that supports the hypothesis that ERß might have a protective role against breast cancer development. The signals that regulate the expression of ERß and its isoforms still remain to be investigated.

Extracellular matrix and hormone receptor expression. The behaviour of mammary epithelial cells as well as breast cancer cells is largely influenced by signals from the extracellular matrix (ECM). Tissue homeostasis, organ morphogenesis, gene expression and cell differentiation, but also cancer development is to a great extent dependent upon 
dynamic interactions between cells and their microenvironment (17-21). ECM molecules and their receptors, of which integrins are the best characterized, have been shown to play an important role in the transduction of cellular signals. The composition of the interstitial stroma and the basement membrane $(\mathrm{BM})$ changes adapting to developmental stages of the mammary gland and also during carcinogenesis $(17,19,22,23)$. The BM is a continuous deposit that separates epithelial cells from the surrounding stroma. Its major components are laminins, collagen type IV, entactin/nidogen, proteoglycans and other glycoproteins $(24,25)$. In BMs of the mammary gland laminin-111 is the predominant laminin isoform (26). BM proteins like collagen type IV and laminin-1 have been shown to regulate ER $\alpha$ and also progesterone receptor $(\mathrm{PgR})$ expression and activity in mammary epithelial and breast cancer cells $(23,27-29)$.

Since there is emerging hope that ERß and its isoforms can be used as prognostic markers or as therapeutic targets for breast cancer in the future it is important to identify signals that regulate ERß expression. Based on the findings on other steroid hormone receptors we hypothesized that signals from the BM can affect ERß expression in breast cancer cells. In the present study we performed assays in a reconstituted laminin-rich BM matrix (Matrigel) using an invasive ER $\alpha$ negative breast cancer cell line (MDA-MB231). In order to investigate the effects of specific BM components we also cultured the cells on coatings of purified laminin-111 and collagen type IV. As a control the same number of MDA-MB-231 cells was cultured on uncoated tissue culture plastic. The expression pattern of ER $\beta$ isoforms was detected by multiplex RT-PCRs.

\section{Materials and methods}

Cell culture. The human breast cancer epithelial cell line MDA-MB-231 was obtained from the American Type Culture Collection (Manassas, USA). The cells were cultured in L-15 Leibowitz-medium (Biochrom, Germany) supplemented with $10 \%$ FCS (Biochrom), L-Glutamin $2 \mathrm{mM}$ (Sigma-Aldrich, Germany) and $1 \%$ penicillin/streptomycin (Biochrom) and kept in $0 \% \mathrm{CO}_{2}$ at $37^{\circ} \mathrm{C}$.

Matrigel assays. In order to investigate the effects of BM components, the cells were cultured on a layer of 'Matrigel ${ }^{\mathrm{TM}}$ basement membrane matrix' (Becton Dickinson, Germany). To test if there is any effect from growth factors we also carried out Matrigel assays using 'Growth factor reduced matrigel basement membrane matrix' (Becton Dickinson). Twenty-four well-plates were coated with Matrigel $\left(100 \mu \mathrm{l} / \mathrm{cm}^{2}\right)$ according to the manufacturer's recommendations ('thin gel method', Becton Dickinson). The Matrigel layer was solidified at $37^{\circ} \mathrm{C}$ for $30 \mathrm{~min}$. We then seeded 100,000 MDA-MB-231 cells, suspended in $500 \mu 1$ medium, into each well. The Matrigel assay system, established in this way, provides a sufficient stimulation of the cells through BM components and enables to retrieve sufficient amounts of RNA. As a control the same number of cells was cultured on uncoated tissue culture plastic under identical conditions. After 24, 48 or $72 \mathrm{~h}$ Matrigel was solubilized enzymatically in dispase (254 $\mu 1 / 24$-well) for $2 \mathrm{~h}$. Cells from six 24 -wells,
Table I. Primer combinations and detected ERß isoforms.

\begin{tabular}{lcl}
\hline Primer combination & Fragment length & Detected ERß isoforms \\
\hline PM1 & $308 \mathrm{bp}$ & ERß1 \\
ERß 1U SP6 sense & & \\
ERß 1L T7 antisense & $254 \mathrm{bp}$ & ERß2/ERß $\Delta 5$ \\
ERß 2L T7 antisense & & \\
PM1 & & ERß5 \\
ERß 1U SP6 sense & $334 \mathrm{bp}$ & ERß2/ERß $\Delta 5$ \\
ERß 2L T7 antisense & $254 \mathrm{bp}$ & \\
PM2 & & ERß1/ERß2 \\
$\begin{array}{l}\text { ERß 5U SP6 sense } \\
\text { ERß LBDL T7 } \\
\text { antisense }\end{array}$ & $228 \mathrm{bp}$ & ERß $\Delta 5$ \\
\end{tabular}

containing cells cultured on Matrigel, were pooled into one Eppendorf tube, centrifuged and pelleted for RNA isolation. Cells cultivated on tissue culture plastic were removed from the wells using trypsin-EDTA $(0.05 \%)$ (Invitrogen, Germany) and prepared for RNA isolation in the same way.

Investigation of collagen type IV and laminin-111. According to the 'coating procedure', recommended by Becton Dickinson, we performed thin coatings of collagen type IV (Becton Dickinson) and laminin-111 (Sigma-Aldrich) on 24-well plates $\left(10 \mu \mathrm{g}\right.$ per $\left.\mathrm{cm}^{2}\right)$. As a control we used uncoated tissue culture plastic to cultivate the cells. Cells $(100,000$ per 24-well) were cultivated on collagen type IV, laminin-111 or tissue culture plastic for $48 \mathrm{~h}$. Trypsin-EDTA was used to remove the cells from the wells. For each experiment cells from 6 wells were trypsinized, pooled and pelleted for RNA isolation.

RNA extraction, cDNA synthesis and RT-PCRs for pyruvate dehydrogenase $(P D H)$. For total RNA extraction we used the RNeasy Mini kit (Qiagen, USA) following the manufacturer's instructions. The amounts of mRNA isolated were determined by spectrophotometry at 260 and $280 \mathrm{~nm}$. RNA $(1 \mu \mathrm{g})$ from each sample was used for RT-PCRs for pyruvate dehydrogenase (PDH) as controls to make sure that no genomic DNA remained in the samples. cDNA was prepared with $2 \mu \mathrm{g}$ of total RNA using the Superscript ${ }^{\mathrm{TM}}$ II RNase H-reverse transcriptase-kit (Invitrogen) according to the manufacturer's directions. To normalize the amounts of cDNA, we carried out RT-PCRs for PDH. The primer pair used for PDH was GGTATGGATGAGGAGCTGGA (sense) and CTTCCA CAGCCCTCGACTAA (antisense). The amplifications were performed for 27 cycles for positive controls and normalization and for 35 cycles for the negative controls. The annealing temperature was $56.3^{\circ} \mathrm{C}$.

Multiplex RT-PCRs for detection of ERß-isoforms. The expression patterns of ER $\beta$ isoforms were detected by multiplex RT-PCRs. Based on the PCR-system described by 

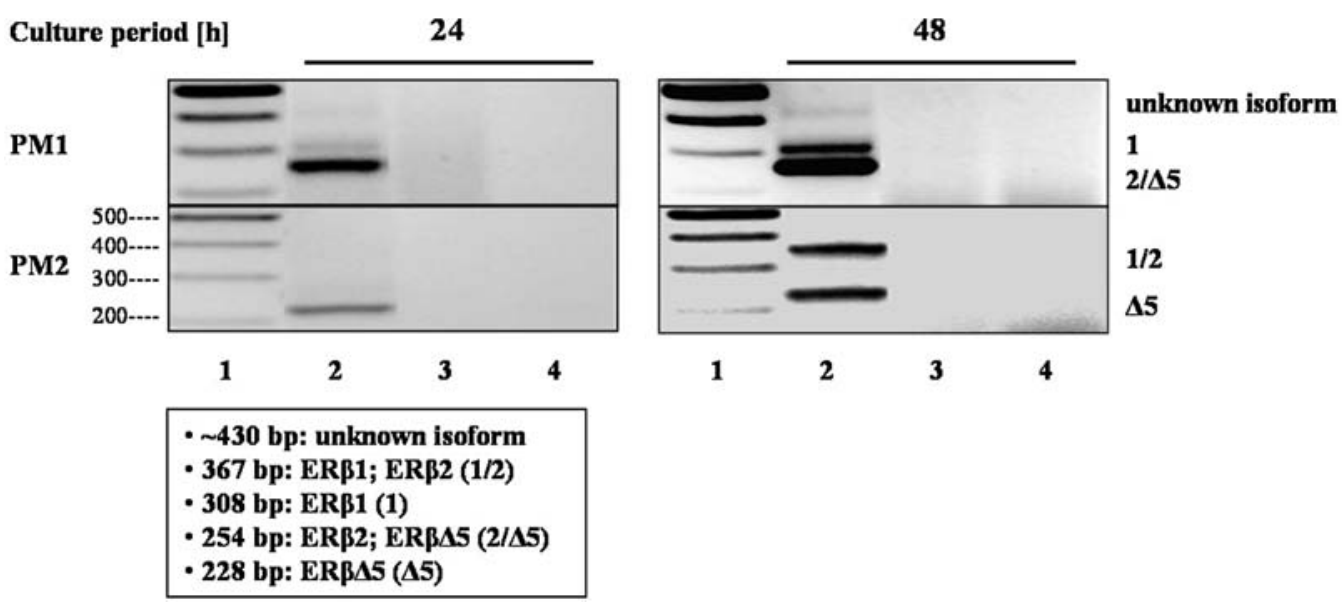

Figure 1. Expression profile for ERß isoforms in MDA-MB-231 cells. Depicted are representative expression profiles of ERß and its isoforms using PM1 and PM2 after cultivation for 24 and $48 \mathrm{~h}$ on plastic cell culture plates. Using PM1 the signal at 254 bp represents ERß2 and ERß $\Delta 5$. The signal at 308 bp detects ERß1. The faint band at $\sim 430 \mathrm{bp}$ is an unknown product. PM2 amplifies ERß $\Delta 5$ (228 bp) and ERß1/ERß2 (367 bp). 1: maker, low range; 2: cDNA from MDA-MB-231 cells; 3: chromosomal DNA; 4: negative control $\left(\mathrm{H}_{2} \mathrm{O}\right)$.

Palmieri et al (30) we established two RT-PCR-systems with different specific primer combinations for ERB isoforms. Primermix 1 (PM1) contains sense primer ERß 1U SP6 (GCATTTAGGTGACACTATAGGGCCGATGCTTT GGTTTGGGTGAT) and both antisense primers ERß 1L T7 (CGTAATACGACTCACTATAGGGCGCCCTCTTTGCT TTTACTG) and ERß 2L T7 (TAATACGACTCACTATAG GGCCGCCTTAGGCCACCGAGTTGATT). Binding sites for Sp6 or T7 RNA polymerase were added for sequencing the PCR fragments. Primermix 2 (PM2) contains the sense primer ERß 5U SP6 (TAATACGACTCACTATAGGGCCG CCTTAGGCCACCGAGTTGATT) and the antisense primer ERß LBDL T7 (TAATACGACTCACTATAGGGCGCGGC CTTGACACAGAGATATTC). In PM1* only ERß 1U SP6 and ERß 2L T7 are used. The reactions for both amplification systems were carried out for 38 cycles with an annealing temperature of $58^{\circ} \mathrm{C}$. All primers were synthesized by Invitrogen. Resulting fragment lengths for each PM are listed in Table I.

\section{Results}

Expression pattern of ERß isoforms in MDA-MB-231 cells. Based on the RT-PCR-system described by Palmieri and colleagues (30) we developed an RT-PCR system approach to detect the expression pattern of ERß isoforms in breast cancer cells. Since this multiplex RT-PCR is a competitive PCR-procedure we also carried out specific PCRs to verify the expression level for each ERß isoform (data not shown). The main isoforms detected in MDA-MB-231 cells are ERß1, ERß2, ERß5 and ERß $\triangle 5$ (Figs. 1 and 4B). MDA-MB231 cells show a distinct expression of ERß at the mRNA stage: ERß2 is predominantly expressed followed by ERß1 (Fig. 1). This basal expression pattern was used as a 'blue print' for all subsequent experiments in which ERß expression on tissue culture plastic was compared to the expression pattern in a laminin rich BM matrix.
Matrigel induces web-like cell morphology. Matrigel showed a strong influence on the organization of the cells. MDAMB-231 cells, cultured on Matrigel, organize in a web-like structure which appears similar to lactiferous ducts (Fig. 2). This phenomenon was observed after $24 \mathrm{~h}$ on Matrigel and was more pronounced after $48 \mathrm{~h}$. The web-like cell organization only occurred on Matrigel, not on purified laminin-111 or collagen type IV (data not shown).

Matrigel basement membrane matrix keeps ERß1 at low levels. MDA-MB-231 cells grown on tissue culture plastic for $24 \mathrm{~h}$ had the same expression pattern for ERß mRNA as cells cultured on Matrigel (Fig. 3). Using PM1 the signal for ERß2/ER $\beta \Delta 5$ was most prominent whereas the signal for ERß1 was very weak and nearly undetectable at $24 \mathrm{~h}$ (Fig. 3). After $48 \mathrm{~h}$ the ERß expression pattern of cells cultivated on Matrigel strongly differed from cells grown on tissue culture plastic. On tissue culture plastic a distinct expression of ERß1 and increased levels of ERß2/ERß $\Delta 5$ were observed. In contrast cells on Matrigel did not up regulate ERß1. The same difference could still be detected after 72 h (Fig. 3). The absence of Matrigel BM matrix seems to up regulate the expression of ERß1 mRNA. Similar results were noted when the experiment was carried out with growth factor reduced Matrigel (data not shown).

Cells grown on laminin-111 but not on collagen type IV show strongly reduced levels of ERß at the mRNA level. Major components of the BM in breast tissue are laminin-111 and collagen type IV. They also are the main constituents of Matrigel. We therefore tested the influence of these proteins on the expression of ERß isoforms in MDA-MB-231 cells. The cultivation of MDA-MB-231 cells on 24 wells coated with laminin-111 for $48 \mathrm{~h}$ indicates that laminin-111 can be correlated with the phenomenon of suppressed ERß1 levels on Matrigel. After $48 \mathrm{~h}$ on laminin-111 a distinct reduction of ERß1 was noted analogous to the results on Matrigel (Fig. 

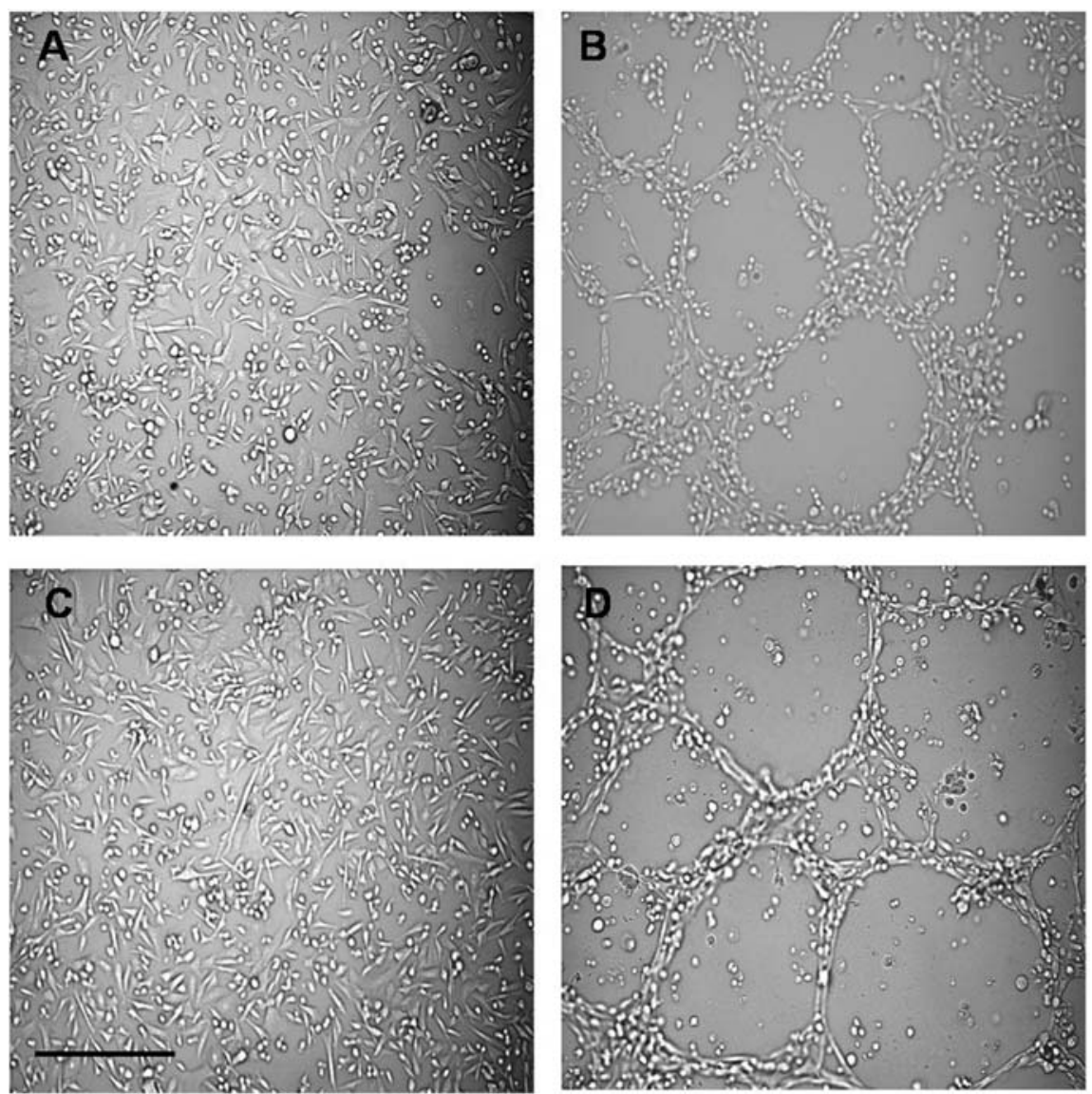

Figure 2. 'Web-like' cell morphology of MDA-MB-231 cells grown on Matrigel BM matrix. Depicted is the morphology of MDA-MB-231 cells after cultivation on plastic or Matrigel. (A) Growth on plastic for $24 \mathrm{~h}$; (B) growth on Matrigel for $24 \mathrm{~h}$; (C) growth on plastic for $48 \mathrm{~h}$; (D) growth on Matrigel for $48 \mathrm{~h}$. Cells grown on Matrigel organize in a 'web-like' structure, which is not observed on plastic. Magnification: x20 (bar indicates $100 \mu \mathrm{m}$ ).

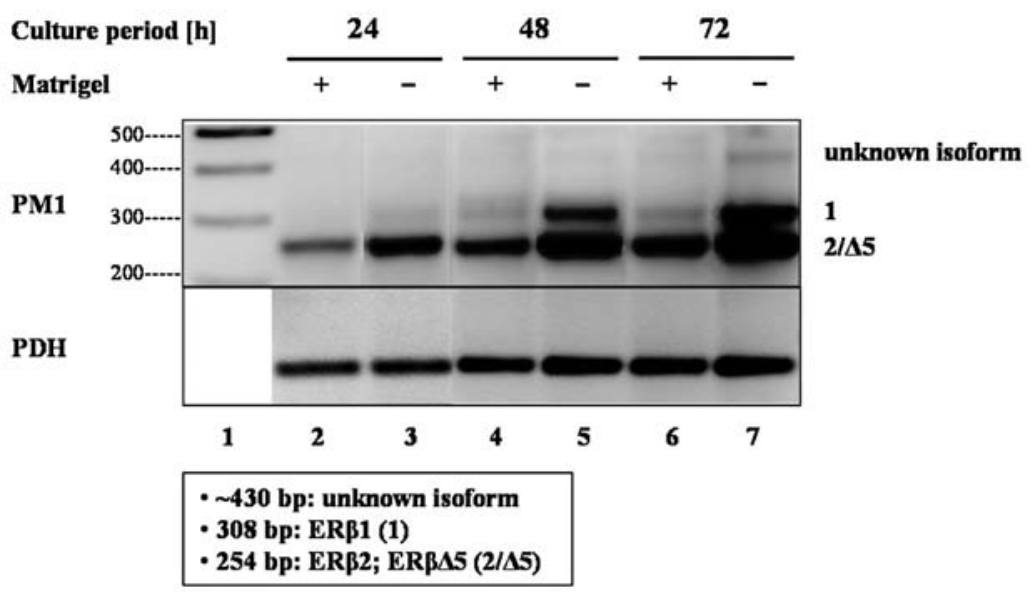

Figure 3. Expression profile of ERß isoforms in MDA-MB-231 cells cultivated on Matrigel. Depicted is a representative expression profile for ERß isoforms after MDA-MB-231 cells were incubated on Matrigel or plastic for 24, 48 and 72 h. 1: marker, low range; 2: growth on Matrigel for $24 \mathrm{~h}$; 3: growth on plastic for $24 \mathrm{~h}$; 4: growth on Matrigel for 48 h; 5: growth on plastic for 48 h; 6: growth on Matrigel for 72 h; 7: growth on plastic for 72 h. RT-PCR was performed using PM1 for ERß. In the lower panel RT-PCR for PDH is depicted for loading control and quality control of each cDNA.

4A). The signal for ERß1 appeared completely repressed. Laminin-111 seems to repress ERß1 expression in MDAMB-231 cells. The expression of the isoforms ERß2, ERß $\Delta 5$ and ERB5 also appeared reduced on laminin-111. To determine in a valid and reliable way which specific isoforms are effected, we carried out ERß RT-PCRs (PM1 and 2) and also ERß RT-PCRs by using the antisense primer ERß 2L T7 of PM1 separately (PM1*) (Fig. 4). When MDA-MB-231 cells were grown on coatings with purified collagen type IV for $48 \mathrm{~h}$ no change in the expression pattern of ERß could 
$\mathbf{A}$

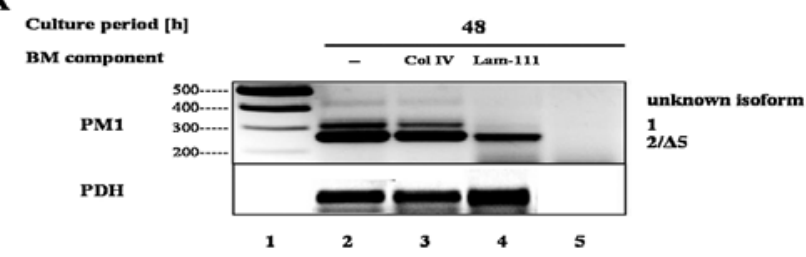

B

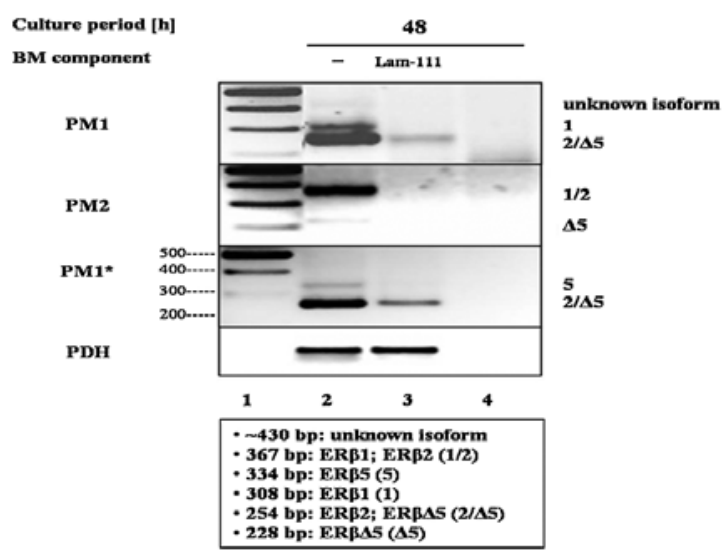

Figure 4. Expression profile of ERß isoforms in MDA-MB-231 cells on laminin-111 or collagen type IV. A representative expression profile for ERß isoforms is shown after the cells have been grown on a thin layer of the basement membrane proteins laminin-111 or collagen type IV. (A) RT-PCR using PM1. 1: marker, low range; 2: growth on plastic; 3: growth on collagen type IV; 4: growth on laminin-111; 5: negative control $\left(\mathrm{H}_{2} \mathrm{O}\right)$. (B) Expression profile for ERß isoforms using PM1, PM2 and PM1*. 1: marker, low range; 2: growth on plastic; 3: growth on laminin-111; 4: negative control $\left(\mathrm{H}_{2} \mathrm{O}\right)$. PCR signals for PDH are depicted for loading control.

be observed compared to growth on tissue culture plastic (Fig. 4A).

\section{Discussion}

A laminin-rich basement membrane influences ERß expression. This study provides evidence for the first time that a reconstituted BM influences the expression of ERß mRNA in breast cancer cells. Most of all the expression of ERß1 appears to be affected. All isoforms detected in this project are known to be translated into ERß proteins $(6,9,31,32)$. Our results indicate that a laminin-rich microenvironment seems to keep ERß1 mRNA expression at low levels. However, the absence of laminin-111 leads to increased levels of ERß1 within $48 \mathrm{~h}$. This effect appears to be specifically induced by laminin-111 as collagen type IV does not lead to a suppression of ERß mRNA.

The effect of ERß regulation by laminin-111 appears to be specific and ERa independent. MDA-MB-231 cells do not express ER $\alpha$. They also stay ER $\alpha$ negative in the presence of all ECM proteins and do not exhibit estrogen inducible proliferation (33). Therefore, it was not necessary to use serum-free medium for our experiments. Our results may raise the question if laminin-111 blocks all transcriptional pathways but several studies prove that this is not the case. A laminin-rich BM induces transcription from the $\beta$ casein promoter by activating a transcriptional enhancer $(34,35)$.
Culture of normal mammary epithelial cells on purified laminin-1 dramatically increases the transcription and synthesis of $\beta$ casein in vitro (36). Also the expression of $\mathrm{ER} \alpha$ is up-regulated by laminin-1 in mammary epithelial cells (27). Therefore, it can be concluded that a lamininmediated suppression of ERß mRNA is likely to be a specific effect. Furthermore, the effect is not dependent on interactions of $\mathrm{BM}$ proteins with $\mathrm{ER} \alpha$ or interactions of $\mathrm{ER} \alpha$ with $\mathrm{ER} \beta$ since MDA-MB-231 is an ER $\alpha$ negative breast cancer cell line.

Integrin receptor signalling may lead to reduced ERß levels. Cell binding to ECM components occurs mainly through surface integrins. Also the maintenance of estrogen receptor $\alpha$ levels in mammary epithelial cells has been shown to be directed by Laminin-1 via integrin receptor signalling (27). Integrins $\alpha 1, \alpha 2, \alpha 6, \alpha 7, \alpha 9$ and $\beta 1$ have been revealed to play a critical role in cell-matrix interactions between mammary epithelial cells and laminin-111 (37-39). Therefore, it is likely that integrin receptor signalling may be responsible for the repression of ERß1 by laminin-111. Another possible signalling pathway could be the $\alpha$-dystroglycan receptor. However, the specific signal transduction mechanism remains to be identified.

Matrigel induces web-like cell organization and migration of MDA-MB-231 cells. Considering the fact that MDA-MB-231 is a highly invasive breast cancer cell line, our Matrigel assay system can be regarded as a three dimensional ECM culture system. The invasive potential of MDA-MB-231 cells leads to a distinct cell invasion into the Matrigel, so the cells are completely surrounded by a laminin-rich BM matrix. Sodunke and colleagues (40) also demonstrated that thin gel coatings of Matrigel lead to the same behaviour of MDAMB-231 cells as the three dimensional Matrigel assays due to the invasion of MDA-MB-231 cells into the Matrigel. The web-like structures which occur after $24 \mathrm{~h}$ in the presence of Matrigel indicate a deep impact of BM components on migration and organization of the tumour cells. Similar weblike or honey comb-like cell formations were seen in the prostate cancer cell lines PC3 $(41,42)$ and DU $145(42,43)$, human airway smooth muscle cells (44) and rat mammary epithelial cells (45) which have been cultured in three dimensional Matrigel assays. It is known that ECM components play a critical role in maintaining differentiation, migration and organization of mammary epithelial cells and also the development of the branched tissue geometry of the mammary gland $(17,18,20,22,46,47)$. Malignant mammary tissue looses its luminal tissue architecture $(19,40,48,49)$. Sodunke and colleagues (40) also found that a single MDA-MB-231 cell grown on Matrigel proliferates in a disorganized way without any web-like formations or luminal cell branching mechanisms. Based on these findings we conclude from the web-like cell organization in the presence of Matrigel that a laminin-rich microenvironment induces migration and aggregation of MDA-MB-231 cells, however, does not induce branching mechanisms or lumen formation of proliferating MDA-MB-231 cells.

Laminin-111 as a possible reason for the loss of ERß in breast cancer carcinogenesis. Several studies revealed that 
ERß seems to be the dominant ER in the mammary gland since ER $\alpha$ expression is much rarer. However, during carcinogenesis ERß1 loss has been described (14-16,50-53). These findings led to a consensus regarding a protective role of ERß1 against breast cancer development (reviewed in ref. 6). However, the mechanisms which lead to a loss of ERß1 during carcinogenesis are still unclear. Methylation has been revealed to be one of the mechanisms that contribute to a down regulation of ERß in cancer (14,54-56). Cell-BM interactions in mammary gland tissue undergo several changes in carcinogenesis $(17,18,20,22)$. Cell-laminin interactions have also been shown to play a role in breast cancer and other carcinomas $(33,38,39)$. Laminin-111 has been shown to be predominantly expressed in the BM of breast tissue (26). Invasive breast cancers also extensively express laminin-111 (57,58). Based on these findings and our main result that laminin-111 seems to suppress ERß1 mRNA it might be speculated that cell-BM interactions between tumour cells and laminin-111 could be responsible for a loss of ERß in the process of carcinogenesis.

Cell-matrix interactions as a future therapeutic target. More and more studies stress that the microenvironment plays a role in the development of cancer (17-20). Since there is emerging consensus that ERB1 can be seen as a tumour suppressor, a loss of ERß1 caused by cell-BM interactions with laminin-111 could be considered as a process which contributes to breast cancer progression. Some studies already focus on new potential approaches for cancer treatment using cell-matrix interactions as a target (reviewed in ref. 20).

Advancing our understanding of the mechanisms by which $\mathrm{BM}$ proteins influence the expression of steroid hormone receptors such as ERß and its isoforms may lead to novel therapeutic approaches for the treatment of breast cancer.

\section{Acknowledgements}

We thank U. Hilcher and K. Geiger for technical support. Laminin-111 was kindly provided by G. Klein, Section for Transplantation Immunology and Immuno-hematology, Centre for Medical Research, University of Tuebingen, Germany.

\section{References}

1.Skliris GP, Leygue E, Watson PH and Murphy LC: Estrogen receptor alpha negative breast cancer patients: estrogen receptor beta as a therapeutic target. J Steroid Biochem Mol Biol 109: 1-10, 2008.

2. Mosselman S, Polman J and Dijkema R: ER beta: identification and characterization of a novel human estrogen receptor. FEBS Lett 392: 49-53, 1996.

3. Speirs V, Carder PJ, Lane S, Dodwell D, Lansdown MR and Hanby AM: Oestrogen receptor beta: what it means for patients with breast cancer. Lancet Oncol 5: 174-181, 2004.

4. Mitter D, Ortmann O and Treeck O: Estrogen receptor Beta isoforms-functions and clinical relevance in breast cancer. Zentralbl Gynakol 127: 228-234, 2005

5. Treeck O, Juhasz-Boess I, Lattrich C, Horn F, Goerse R and Ortmann O: Effects of exon-deleted estrogen receptor beta transcript variants on growth, apoptosis and gene expression of human breast cancer cell lines. Breast Cancer Res Treat 110: 507-520, 2008.

6. Zhao C, Dahlman-Wright $\mathrm{K}$ and Gustafsson JA: Estrogen receptor beta: an overview and update. Nucl Recept Signal 6: E003, 2008.
7. Poola I, Abraham J and Baldwin K: Identification of ten exon deleted ERbeta mRNAs in human ovary, breast, uterus and bone tissues: alternate splicing pattern of estrogen receptor beta mRNA is distinct from that of estrogen receptor alpha. FEBS Lett 516: 133-138, 2002.

8. Mandusic V, Nikolic-Vukosavljevic D, Tanic N, Kanjer K, Neskovic-Konstantinovic Z, Celeketic D and Dimitrijevic B: Expression of estrogen receptor beta wt isoform (ERbeta1) and ERbetaDelta5 splice variant mRNAs in sporadic breast cancer. J Cancer Res Clin Oncol 133: 571-579, 2007.

9. Leung YK, Mak P, Hassan S and Ho SM: Estrogen receptor (ER)-beta isoforms: a key to understanding ER-beta signaling. Proc Natl Acad Sci USA 103: 13162-13167, 2006.

10. Lewandowski S, Kalita K and Kaczmarek L: Estrogen receptor beta. Potential functional significance of a variety of mRNA isoforms. FEBS Lett 524: 1-5, 2002.

11. Moore JT, McKee DD, Slentz-Kesler K, et al: Cloning and characterization of human estrogen receptor beta isoforms. Biochem Biophys Res Commun 247: 75-78, 1998.

12. Skliris GP, Parkes AT, Limer JL, Burdall SE, Carder PJ and Speirs V: Evaluation of seven oestrogen receptor beta antibodies for immunohistochemistry, western blotting, and flow cytometry in human breast tissue. J Pathol 197: 155-162, 2002.

13. Esslimani-Sahla M, Kramar A, Simony-Lafontaine J, Warner M, Gustafsson JA and Rochefort H: Increased estrogen receptor betacx expression during mammary carcinogenesis. Clin Cancer Res 11: 3170-3174, 2005.

14. Skliris GP, Munot K, Bell SM, et al: Reduced expression of oestrogen receptor beta in invasive breast cancer and its reexpression using DNA methyl transferase inhibitors in a cell line model. J Pathol 201: 213-220, 2003.

15. Speirs V, Adams IP, Walton DS and Atkin SL: Identification of wild-type and exon 5 deletion variants of estrogen receptor beta in normal human mammary gland. J Clin Endocrinol Metab 85: 1601-1605, 2000.

16. Shaw JA, Udokang K, Mosquera JM, Chauhan H, Jones JL and Walker RA: Oestrogen receptors alpha and beta differ in normal human breast and breast carcinomas. J Pathol 198: 450-457, 2002.

17. Kass L, Erler JT, Dembo M and Weaver VM: Mammary epithelial cell: influence of extracellular matrix composition and organization during development and tumorigenesis. Int $\mathbf{J}$ Biochem Cell Biol 39: 1987-1994, 2007.

18. Nelson CM and Bissell MJ: Of extracellular matrix, scaffolds, and signaling: tissue architecture regulates development, homeostasis, and cancer. Annu Rev Cell Dev Biol 22: 287-309, 2006.

19. Bissell MJ, Kenny PA and Radisky DC: Microenvironmental regulators of tissue structure and function also regulate tumor induction and progression: the role of extracellular matrix and its degrading enzymes. Cold Spring Harb Symp Quant Biol 70: 343-356, 2007.

20. Berrier AL and Yamada KM: Cell-matrix adhesion. J Cell Physiol 213: 565-573, 2007.

21. Streuli CH, Bailey $\mathrm{N}$ and Bissell MJ: Control of mammary epithelial differentiation: basement membrane induces tissuespecific gene expression in the absence of cell-cell interaction and morphological polarity. J Cell Biol 115: 1383-1395, 1991.

22. Fata JE, Werb Z and Bissell MJ: Regulation of mammary gland branching morphogenesis by the extracellular matrix and its remodeling enzymes. Breast Cancer Res 6: 1-11, 2004.

23. Xie J and Haslam SZ: Extracellular matrix regulates ovarian hormone-dependent proliferation of mouse mammary epithelial cells. Endocrinology 138: 2466-2473, 1997.

24. Kalluri R: Basement membranes: structure, assembly and role in tumour angiogenesis. Nat Rev Cancer 3: 422-433, 2003.

25. Timpl R: Macromolecular organization of basement membranes. Curr Opin Cell Biol 8: 618-624, 1996.

26. Virtanen I, Gullberg D, Rissanen J, et al: Laminin alpha1-chain shows a restricted distribution in epithelial basement membranes of fetal and adult human tissues. Exp Cell Res 257: 298-309, 2000.

27. Novaro V, Roskelley CD and Bissell MJ: Collagen-IV and laminin-1 regulate estrogen receptor alpha expression and function in mouse mammary epithelial cells. J Cell Sci 116: 2975-2986, 2003.

28. Sisci D, Aquila S, Middea E, et al: Fibronectin and type IV collagen activate ERalpha AF-1 by c-Src pathway: effect on breast cancer cell motility. Oncogene 23: 8920-8930, 2004. 
29. Yang J, Liu A, Dougherty C, Chen X, Guzman R and Nandi S: Estrogen and progesterone receptors can be maintained in normal human breast epithelial cells in primary culture and after transplantation into nude mice. Oncol Rep 7: 17-21, 2000.

30. Palmieri C, Saji S, Sakaguchi H, et al: The expression of oestrogen receptor (ER)-beta and its variants, but not ERalpha, in adult human mammary fibroblasts. J Mol Endocrinol 33: $35-50,2004$

31. Peng B, Lu B, Leygue E and Murphy LC: Putative functional characteristics of human estrogen receptor-beta isoforms. J Mol Endocrinol 30: 13-29, 2003.

32. Cheng G, Li Y, Omoto Y, et al: Differential regulation of estrogen receptor (ER)alpha and ERbeta in primate mammary gland. J Clin Endocrinol Metab 90: 435-444, 2005.

33. Woodward TL, Lu H and Haslam SZ: Laminin inhibits estrogen action in human breast cancer cells. Endocrinology 141: 2814-2821, 2000

34. Schmidhauser C, Casperson GF, Myers CA, Sanzo KT, Bolten S and Bissell MJ: A novel transcriptional enhancer is involved in the prolactin-and extracellular matrix-dependent regulation of beta-casein gene expression. Mol Biol Cell 3: 699-709, 1992.

35. Streuli CH, Schmidhauser C, Bailey N, Yurchenco P, Skubitz AP, Roskelley $\mathrm{C}$ and Bissell MJ: Laminin mediates tissue-specific gene expression in mammary epithelia. J Cell Biol 129: 591-603, 1995.

36. Schmidhauser C, Bissell MJ, Myers CA and Casperson GF: Extracellular matrix and hormones transcriptionally regulate bovine beta-casein $5^{\prime}$ sequences in stably transfected mouse mammary cells. Proc Natl Acad Sci USA 87: 9118-9122, 1990.

37. Nishiuchi R, Takagi J, Hayashi M, et al: Ligand-binding specificities of laminin-binding integrins: a comprehensive survey of laminin-integrin interactions using recombinant alpha3beta1, alpha6beta1, alpha7beta 1 and alpha6beta 4 integrins. Matrix Biol 25: 189-197, 2006.

38. Schéele S, Nyström A, Durbeej M, Talts JF, Ekblom M and Ekblom P: Laminin isoforms in development and disease. J Mol Med 85: 825-836, 2007.

39. Mercurio AM, Bachelder RE, Chung J, O'Connor KL, Rabinovitz I, Shaw LM and Tani T: Integrin laminin receptors and breast carcinoma progression. J Mammary Gland Biol Neoplasia 6: 299-309, 2001

40. Sodunke TR, Turner KK, Caldwell SA, McBride KW, Reginato MJ and Noh HM: Micropatterns of Matrigel for threedimensional epithelial cultures. Biomaterials 28: 4006-4016, 2007.

41. Lang SH, Sharrard RM, Stark M, Villette JM and Maitland NJ: Prostate epithelial cell lines form spheroids with evidence of glandular differentiation in three-dimensional Matrigel cultures. Br J Cancer 85: 590-599, 2001.

42. Gopal P, Rehman RU, Chadha KS, Qiu M and Colella R: Matrigel influences morphology and cathepsin B distribution of prostate cancer PC3 cells. Oncol Rep 16: 313-320, 2006

43. Webber MM, Bello D, Kleinman HK and Hoffman MP: Acinar differentiation by non-malignant immortalized human prostatic epithelial cells and its loss by malignant cells. Carcinogenesis 18: 1225-1231, 1997.

44. Hirst SJ, Twort CH and Lee TH: Differential effects of extracellular matrix proteins on human airway smooth muscle cell proliferation and phenotype. Am J Respir Cell Mol Biol 23: $335-344,2000$
45. Larsen MC, Brake PB, Pollenz RS and Jefcoate CR: Linked expression of Ah receptor, ARNT, CYP1A1, and CYP1B1 in rat mammary epithelia, in vitro, is each substantially elevated by specific extracellular matrix interactions that precede branching morphogenesis. Toxicol Sci 82: 46-61, 2004.

46. Petersen OW, Ronnov-Jessen L, Weaver VM and Bissell MJ: Differentiation and cancer in the mammary gland: shedding light on an old dichotomy. Adv Cancer Res 75: 135-161, 1998.

47. Lanigan F, O'Connor D, Martin F and Gallagher WM: Molecular links between mammary gland development and breast cancer. Cell Mol Life Sci 64: 3159-3184, 2007.

48. Itoh M, Nelson CM, Myers CA and Bissell MJ: Rap1 integrates tissue polarity, lumen formation, and tumorigenic potential in human breast epithelial cells. Cancer Res 67: 4759-4766, 2007.

49. Muthuswamy SK, Li D, Lelievre S, Bissell MJ and Brugge JS: ErbB2, but not ErbB1, reinitiates proliferation and induces luminal repopulation in epithelial acini. Nat Cell Biol 3: 785-792, 2001.

50. Iwao K, Miyoshi Y, Egawa C, Ikeda N, Tsukamoto F and Noguchi S: Quantitative analysis of estrogen receptor-alpha and-beta messenger RNA expression in breast carcinoma by real-time polymerase chain reaction. Cancer 89: 1732-1738, 2000.

51. Leygue E, Dotzlaw H, Watson PH and Murphy LC: Altered estrogen receptor alpha and beta messenger RNA expression during human breast tumorigenesis. Cancer Res 58: 3197-3201, 1998.

52. Dotzlaw H, Leygue E, Watson PH and Murphy LC: Expression of estrogen receptor-beta in human breast tumors. J Clin Endocrinol Metab 82: 2371-2374, 1997.

53. Roger P, Sahla ME, Mäkelä S, Gustafsson JA, Baldet P and Rochefort H: Decreased expression of estrogen re-ceptor beta protein in proliferative preinvasive mammary tumors. Cancer Res 61: 2537-2541, 2001.

54. Sasaki M, Tanaka Y, Perinchery G, Dharia A, Kotcherguina I, Fujimoto S and Dahiya R: Methylation and inactivation of estrogen, progesterone, and androgen receptors in prostate cancer. J Natl Cancer Inst 94: 384-390, 2002.

55. Zhao C, Lam EW, Sunters A, et al: Expression of estrogen receptor beta isoforms in normal breast epithelial cells and breast cancer: regulation by methylation. Oncogene 22: 7600-7606, 2003.

56. Lazennec G, Bresson D, Lucas A, Chauveau C and Vignon F: ER beta inhibits proliferation and invasion of breast cancer cells. Endocrinology 142: 4120-4130, 2001.

57. Fujita M, Khazenzon NM, Bose S, et al: Overexpression of beta1-chain-containing laminins in capillary basement membranes of human breast cancer and its metastases. Breast Cancer Res 7: R411-R421, 2005.

58. Ronnov-Jessen L, Petersen OW and Bissell MJ: Cellular changes involved in conversion of normal to malignant breast: importance of the stromal reaction. Physiol Rev 76: 69-125, 1996. 